\title{
Ophavsret til \\ undervisningsmateriale
}

\section{Morten Rosenmeier}

Professor, KU, og formand for Udvalget til

Beskyttelse af Videnskabeligt Arbejde (UBVA)

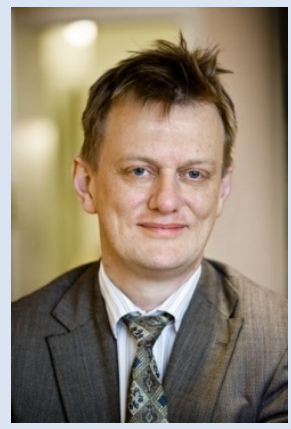

Morten Rosenmeier er professor i immaterialret ved Det Juridiske Fakultet, KU, og formand for UBVA. Han har skrevet forskellige bøger om ophavsret mv. Man kan se mere om ham på hans hjemmeside:

www.jur.ku.dk/mortenrosenmeier. 


\section{Ophavsret til undervisningsmateriale}

UNI-C og ACs Udvalg til Beskyttelse af Videnskabeligt Arbejde - forkortet "UBVA" - driver sammen tjenesten "E-læring og jura" på www.unic.dk/jura. Her fortæller vi ved hjælp af artikler, film, tegnefilm, quizzer m.m. undervisere ved danske uddannelsesinstitutioner om, hvordan det juridiske klaver spiller, når det kommer til e-læring. Må man bruge musik fra Youtube i sin e-læring? Må man krydre sine slides med billeder? Kan brug af stillbilleder fra en film være et lovligt citat fra filmen? Få svaret på det, og meget mere, på www.uni-c.dk/jura. Man kan også stille spørgsmål til os på vores Jurablog, hvis man har noget, man ikke synes man kan finde noget om på hjemmesiden.

Ét af de spørgsmål, vi tit bliver stillet over for, er: En lærer arbejder på en uddannelsesinstition. Den har lige investeret i et kostbart Databasesystem. Ledelsen ønsker, at læreren og hans kolleger uploader deres undervisningsmateriale til databasen, sådan så lærerne kan genbruge hinandens materiale. Skal læreren acceptere det? Hvem har ophavsretten til undervisningsmateriale? Kan en lærer, der har uploadet sit materiale til systemet, hive det ned igen? Eller tage det med, hvis han eller hun skifter arbejdsplads?

Det juridiske svar lyder, at det som principielt udgangspunkt er læreren selv, der har ophavsret til sit undervisningsmateriale.

Uddannelsesinstitutionen kan kun sætte sig på ophavsretten, hvis det er foreneligt med principper om ophavsret i ansættelsesforhold. Det vil igen sige, at den kun kan disponere over de ansattes værker på den måde, den har gjort før, gennem en vis tid. Derimod kan den ikke begynde på noget, der indebærer nye måder at bruge de ansattes værker på. En institution, der ikke plejer at blande sig i, hvad de ansatte gør med deres undervisningsmateriale, kan derfor ikke pludselig begynde på det. Læs mere i UBVAs bog "Ophavsret for begyndere" kapitel 7, afsnit K. Man kan downloade bogen fra E-læring og jura-portalen.

Noget andet er imidlertid, at der også er nogle undervisere, der synes det er en god idé at dele deres undervisningsmateriale med deres kolleger, og derfor godt vil være med til at lægge det ud i et vist omfang. UBVA anbefaler derfor, at uddannelsesinstitutionerne og de ansatte indgår nogle kollektive aftaler om ophavsretten til undervisningsmateriale. Det er vigtigt, at aftalerne er tænkt ordentligt igennem.

- Hvad er det for materiale, der skal lægges ud?

- Kan lærere tage deres materiale ned igen, når først de har lagt det ud?

- Må man tage sit materiale med sig, når man rejser? 
Vi vil inden for den nærmeste fremtid lægge anbefalinger om, hvad vi mener der skal stå i aftalerne, ud på E-læring og jura-portalen.

Vi ses forhåbentlig der - www.uni-c.dk/jura 